\title{
Developing of Sustainability Balanced Scorecard for the Chemical Industry: Preliminary Evidence from a Case Analysis
}

\author{
Gyula Fulop ${ }^{1}$, Bettina Hernadi ${ }^{1}$, Marjan Jalali $^{2}$, Ieva Meidute-Kavaliauskiene ${ }^{2,3}$, Fernando \\ Ferreira $^{2,4}$
}

${ }^{1}$ Institute of Business Sciences, University of Miskolc

3515 Miskolc-Egyetemvaros, Hungary

E-mail:vgtfulop@uni-mikolc.hu,vgtbetti@uni-mikolc.hu

${ }^{2}$ ISCTE Business School, BRU-IUL, University Institute of Lisbon

Avenida das Forcas Armadas, 1649-026 Lisbon, Portugal

E-mail: marjan.jalali@iscte.pt, ieva.meidute@vgtu.lt,fernando.alberto.ferreira@iscte.pt

${ }^{3}$ Faculty of Business Management, Vilnius Gediminas Technical University

Sauletekio av. 11, LT-10223, Vilnius, Lithuania

E-mail: ieva.meidute-kavaliauskiene@vgtu.lt

${ }^{4}$ Fogelman College of Business and Economics, University of Memphis

Memphis, TN 38152-3120, USA

E-mail: fernando.ferreira@memphis.edu

cross $^{\text {ref }}$ http://dx.doi.org/10.5755/j01.ee.25.3.6424

\begin{abstract}
Companies today operate in an increasingly turbulent environment, with multiple (and sometimes competing) demands. Among these there is sustainability. No longer merely a buzzword, sustainability is becoming a mainstay of organizational operations, and a strategic pre-requisite for long term competitive advantages and business excellence. Crafting and implementing of strategy adapted to the company's external context and internal resources and capabilities are fundamental, and sustainability needs to be a central element to any such strategy. As such, tools are required that can bring these components together. Long used for performance management and strategic management more generally, the Balanced Scorecard (BSC) could plausibly constitute such a framework, if appropriately extended to include sustainability concerns. The aim of this paper is thus to develop such an extension, through creation of a Sustainability Balanced Scorecard (SBSC), which includes social and environmental perspectives and their interactions with the traditional perspectives. We outline the structure for a SBSC, which takes companies' overall sustainability objectives into account, as well as the steps required for its development. A case study of the formation and introduction of a "credible" sustainability strategy in the chemical industry is presented. The results demonstrate the usefulness of the SBSC in pursuing sustainability strategies, and provide preliminary evidence that introduction of such a system is likely to lead to fundamental changes in the way a company is managed. Practical implications and managerial guidelines are also reported.
\end{abstract}

Keywords: balanced scorecard, business performance, corporate strategy, economic development, sustainability strategy.

\section{Introduction}

Globalization, sustainability, ethical competences, quality, information and communication technology (ICT) applications, labor force diversity and business excellence in general are central concerns for most companies. As these issues combine to interact, the turbulence of the external environment increases, and strategy-making becomes even more important, not only to help companies stay afloat, but to contribute to their successful operations. Within this strategy-making, sustainability is an increasingly important requirement, with the implication that for most companies, the social and eco-friendly nature of their activities will soon become one of the most important factors of their competitiveness (Kolk, 2000; Garvare \& Johansson, 2010).

Given this background, this paper builds on previous works of (Bieker, 2003; Fulop \& Hernadi, 2012), and aims to contribute to the successful formation and implementation of corporate strategies for sustainability and business excellence, through the development and practical application of an extended Balanced Scorecard (BSC), which includes both social and environmental perspectives. It should be highlighted, however, that our proposal goes beyond mere additions of the environmental and social perspectives, to recognize their interaction with the traditional BSC perspectives, and include sustainability related goals within them. In this sense, we outline the structure for a Sustainability Balanced Scorecard (SBSC) and the steps required for its development and practical application, contributing to closing the gap between principle and action at the business level. Through the application of our SBSC in a chemical company, our interest lies in the creation of a framework which can help companies to define those all-important sustainability goals and develop a sustainability strategy. 
In the remainder of the present paper, the theoretical grounding of the proposed framework is developed. Its adoption and implementation in one of the largest chemical companies in Hungary is then described, and relevant details on the procedural steps followed and the managerial implications of the sustainability system reported.

\section{Sustainability-Oriented Options}

Kardos (2012, p. 1167) defends that "the concept of sustainable development [...] has had a significant and lasting impact on the development agenda in the last decades, from global to local". For companies, this has meant having a strategy, which meets the expectations of both the company's present and future stakeholders, without making any crucial compromises in terms of skills and capabilities (Bieker et al., 2002; Liming et al., 2008; Kardos, 2012).

In previous studies by (Dyllick, 1999; Bieker et al., 2002), competitive environmental strategies have been classified on the basis of the company's strategic orientation and its strategic behavior. In what refers to sustainability issues, there are not only market forces at play, but societal ones as well. Strategic orientation therefore refers to managers' perceptions of the relative importance of these two elements: the society/the public or the market. Strategic behavior, in turn, refers to the adopted level of defensiveness or offensiveness in the company's approach to sustainability issues: whether they are proactive or reactive with regard to such concerns. When these two factors are combined, different types of sustainability strategies can be formulated, as illustrated in Figure 1.

\begin{tabular}{|c|c|c|}
$\begin{array}{r}\text { Strategic } \\
\text { Orientation } \\
\text { Strategic } \\
\text { Behavior }\end{array}$ & Public & Market \\
\hline Reactive & $\begin{array}{c}\text { "Credible" } \\
\text { Strategy }\end{array}$ & "Efficient" Strategy \\
\hline Proactive & $\begin{array}{c}\text { "Transformative" } \\
\text { Strategy }\end{array}$ & "Innovative" Strategy \\
\hline
\end{tabular}

Figure 1. Four different types of sustainability strategies (Adapted from Bieker et al., 2002)

A "credible" strategy is essentially reactive and oriented towards society. It aims towards the enhancement and fostering of credibility and reputation, recognizing that these can be valuable non-tangible assets (Bieker, 2003). An "efficient" sustainability strategy is similarly reactive, but more focused on the market. It is a strategy best suited to the industrial sector, and the aim is to enhance productivity as well as ecological and social efficiency. A sustainability strategy proactively focusing on the market is termed "innovative", and aims to reap the potential for market differentiation on the basis of sustainability, i.e. products' or services' environmentally and socially friendly attributes. Finally, "transformative" strategies are proactive and turned towards the public. They aim to "create or participate in structural changes in the institutional framework of markets and politics" (Bieker,
2003 , p. 26) and, as such, entail greater changes, namely at the institutional level.

Underlying these sustainability strategies are both internal and external factors (Ghobadian et al., 1998; Fink et al., 2005). The next section discusses how these variables can be linked and used for the implementation of sustainability strategies and business excellence.

\section{Implementation of Sustainability Strategies: Moving Beyond Simple BSC Extensions}

A management tool increasingly used for performance management, and for strategic management more broadly, is the BSC (Kaplan \& Norton, 1992; 1996). Atkinson (2006, p. 1441) notes that the BSC "can address the key problems associated with strategy implementation including communication, the role of middle managers and integration with existing control systems". As such, there has been a massive surge in the popularity of this instrument since its introduction in the early 1990s in both management theory and practice ( $c f$. Fernandes et al., 2006; Chang et al., 2008; Agostino \& Arnaboldi, 2012; Ferreira, 2013). This paper proposes an extension of the BSC, which can help companies to define their sustainability goals, and develop and monitor their sustainability strategy accordingly.

It should be noted that the idea of using the BSC for environmental management purposes is not new ( $c f$. Kaplan \& Norton, 2001, 2004; Bieker, 2003). Wynder (2010, p. 225) observes that "a number of authors have advocated a separate sustainability scorecard [...]. Others have argued for incorporating sustainability in the organization's existing BSC [...], either as a separate perspective or integrated throughout the existing perspectives" (for further discussion and/or examples, see Epstein \& Wisner, 2001; Bieker \& Waxenberger, 2002; Dias-Sardinha et al., 2002 and 2007; Butler et al., 2011).

A common approach to extending of the BSC has been to add the social and environmental perspectives to it (e.g. Jones, 2011). The need for both these elements is emphasized by the Kyoto Convention, as well as various other environmental laws and regulations ( $c f$. Figge et al., 2002; Liming et al., 2008; Ghazinoory \& Soofi, 2012; Simon et al., 2013). However, merely adding two more perspectives to the BSC fails to consider their specific components, as well as, crucially, their impact on the traditional perspectives. Such an approach can arguably undermine social and environmental reliability. First, listing of social and environmental factors into individual perspectives rather than seeing them as criteria for all corporate activities and decisions is more dividing than integrating. So while both the social and the environmental perspective are added, counter-intuitively, they end up detached from one another in practice. Second, these simple addition approaches focus on the social and environmental consequences of company's actions; they take into account ecological footprint but do not allow the capabilities and forces driving it to be identified. As a result, they show end results, but do not explain why they emerge, nor how they can be improved. Finally, cause-andeffect relationships that should be included in the BSC and 
its strategy maps cannot be delineated, which means that a true sustainability strategy cannot be outlined.

A more desirable aim would therefore be to demonstrate how company's capabilities and knowledge can be applied to its activities to reduce social and environmental damage. For this, an extension of the BSC that goes beyond simple additions is required. Building on previous works of (Bieker, 2003; Fulop \& Hernadi, 2012), we develop a comprehensive SBSC, comprising different views for the integration of sustainability issues. Our proposal for this extension is presented in the next section.

\section{Structure and Steps for a New Sustainability Framework}

The SBSC proposed in this paper builds on the traditional BSC by providing a wider framework, in which both other stakeholders and the dimensions of sustainability are integrated with the traditional perspectives. This results in a (Sustainability) Balanced Scorecard containing different content and different structure, as illustrated in Figure 2.

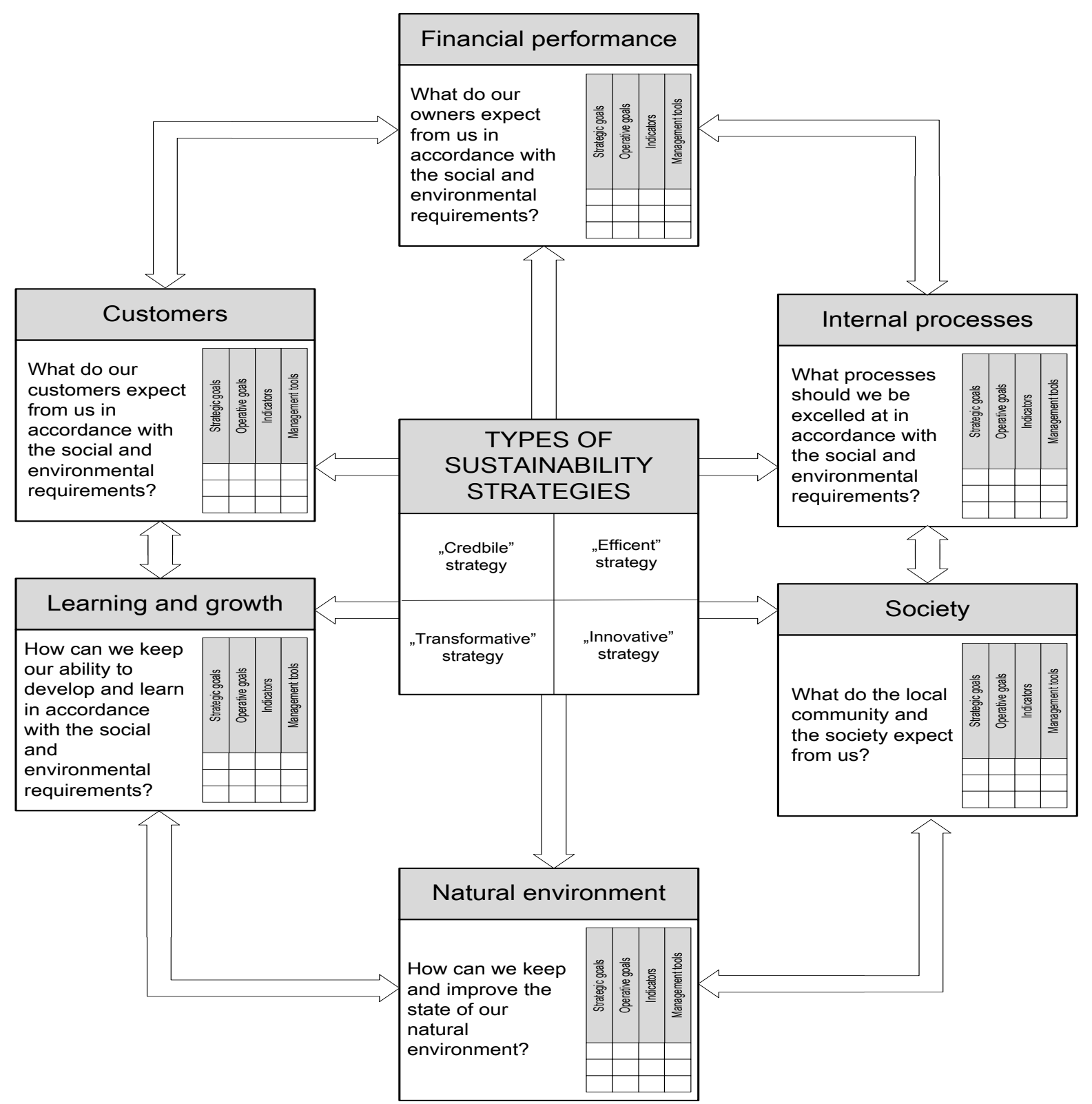

Figure 2. Sustainability strategies and structure of the SBSC (Fulop \& Hernadi, 2012)

This SBSC introduces the social and environmental perspectives, so that the goals pertaining to these perspectives can be clearly and directly delineated. The novelty, however, lies in that these social and environmental expectations are also integrated into the traditional perspectives during a goal formulation. The idea is that the objectives set in these traditional perspectives should be in accordance with the previously determined sustainability strategy. Figure 2 illustrates this by placing sustainability strategies at the centre of the framework. It becomes clear, then, that the task of designing and analysing a SBSC is a complex one. A step-by-step approach to this is presented in Figure 3.

As illustrated in Figure 3, the essence of the SBSC like that of the BSC - is to translate strategy into action ( $c f$. Sminia, 2005; Wong et al., 2009). However, in this case, 
Gyula Fulop, Bettina Hernadi, Marjan Jalali, Ieva Meidute-Kavaliauskiene, Fernando Ferreira. Developing of

the scorecard takes into consideration that "in order to be sustainable, a company must be innovative at several levels to minimize the environmentally negative impact that it generates" (Sarmento et al., 2007, p. 920). Therefore, the process begins with the definition of strategic inputs, such as vision and mission, and also of environmental and social responsibility. The appropriate sustainability strategy can then be defined, and the company's strategic goals as well as the connections between them derived there (for further discussion, see also Kraus \& Lind, 2012; Ubius \& Alas, 2012; Petrokaite \& Stravinskiene, 2013).

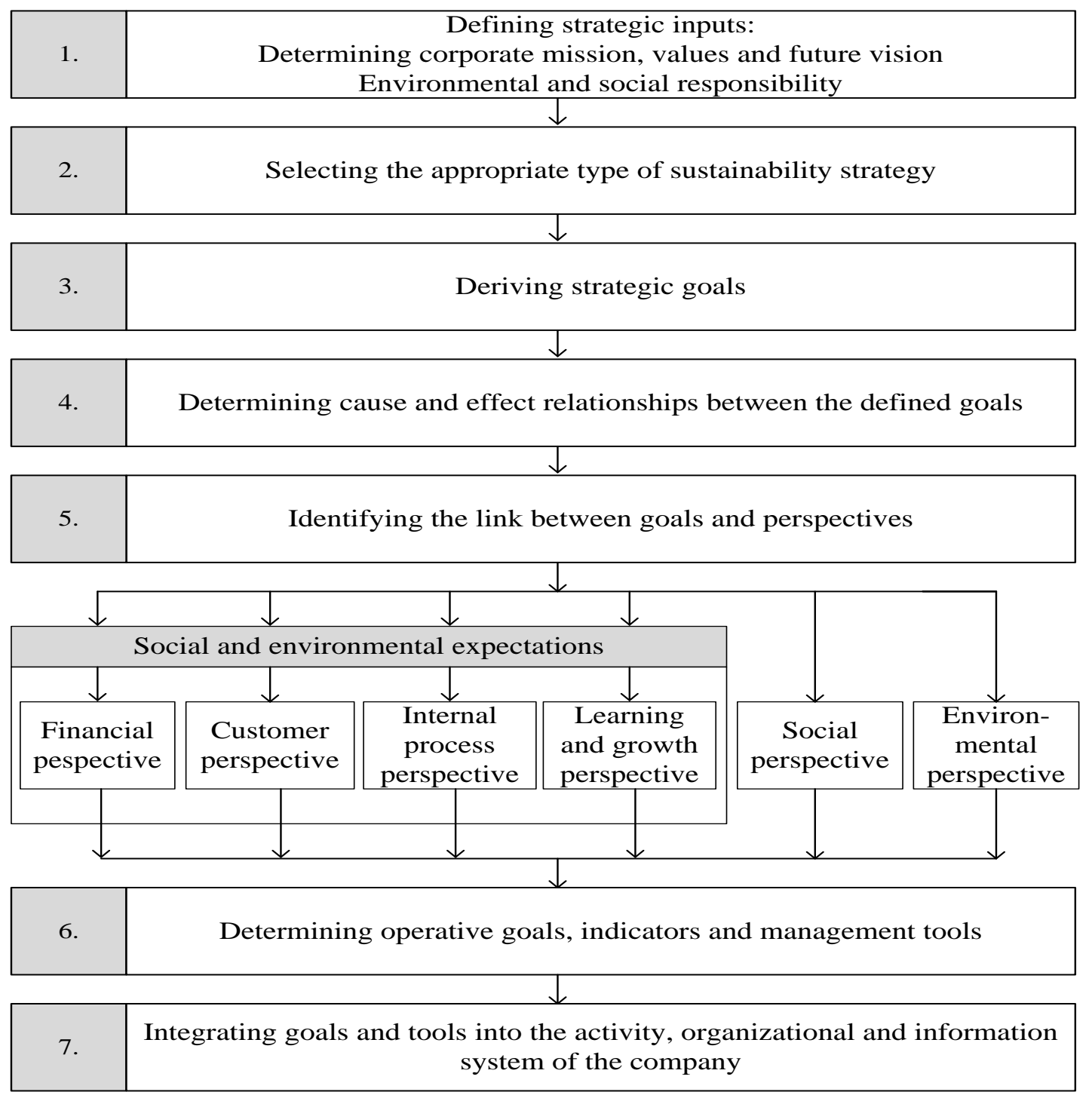

Figure 3. Defined set of steps of the SBSC (Fulop \& Pelczne, 2011)

\section{Implementing of the Proposed Framework}

This section describes an application of the principles of sustainable development in one of Hungary's largest chemical companies. The Tiszai Vegyi Kombinat Public Limited Company (TVK) currently has 1097 employees and annual sales revenues of around 374584 million HUF. The company makes ethylene and propylene by processing naphtha and gasoline as raw materials, and in addition supplies raw materials to domestic and foreign plastic manufacturing companies throughout Europe.

The reasons for the choice of this company in particular are bound with: (1) its size and significance within the country context; (2) its existing concerns with social and environmental issues; (3) its familiarity with the traditional BSC; and, finally, (4) its accessibility and willingness to cooperate with the research project. Indeed, TVK is one of Hungary's leading corporations and had been using the traditional BSC for over six years when initially contacted by the researchers regarding the development of the Sustainability Scorecard. Meetings were held with top management, and the actual process of developing and implementing of the SBSC was accompanied by the Head of the Department for Sustainable Development, which is responsible for the company's health and safety, insurance and environmental issues.

\section{Map of TVK's “credible” sustainability strategy and its $S B S C$}

Although committed to sustainable development and business excellence, TVK's initiatives in this regard have been mostly in reaction to stakeholder and contextual 
demands and requirements. The company is careful to clearly communicate its achievements in this field to all its stakeholders, external ones in particular. Special attention is paid to ecological concerns regarding the creation of a cleaner environment; and to health and safety issues within the workplace. The principles of sustainability, environment-oriented thinking and business excellence are deeply embedded in the company's long-term strategy. TVK's sustainability strategy was thus classified as "credible". From this starting point, the goals associated with the company's credible strategy, its components, and the cause and effect relationships between them were determined and drawn out in the strategy map presented in Figure 4, a necessary step for "the successful implementation of the Balanced Scorecard" (Othman, 2006, p. 690). The map thus illustrates how the company's intangible assets, such as employee satisfaction and commitment, or its sustainability-oriented culture, can lead to performance improvements in those internal processes that have the most significant influence on TVK's value creation for shareholders, customers, social communities and natural environment.

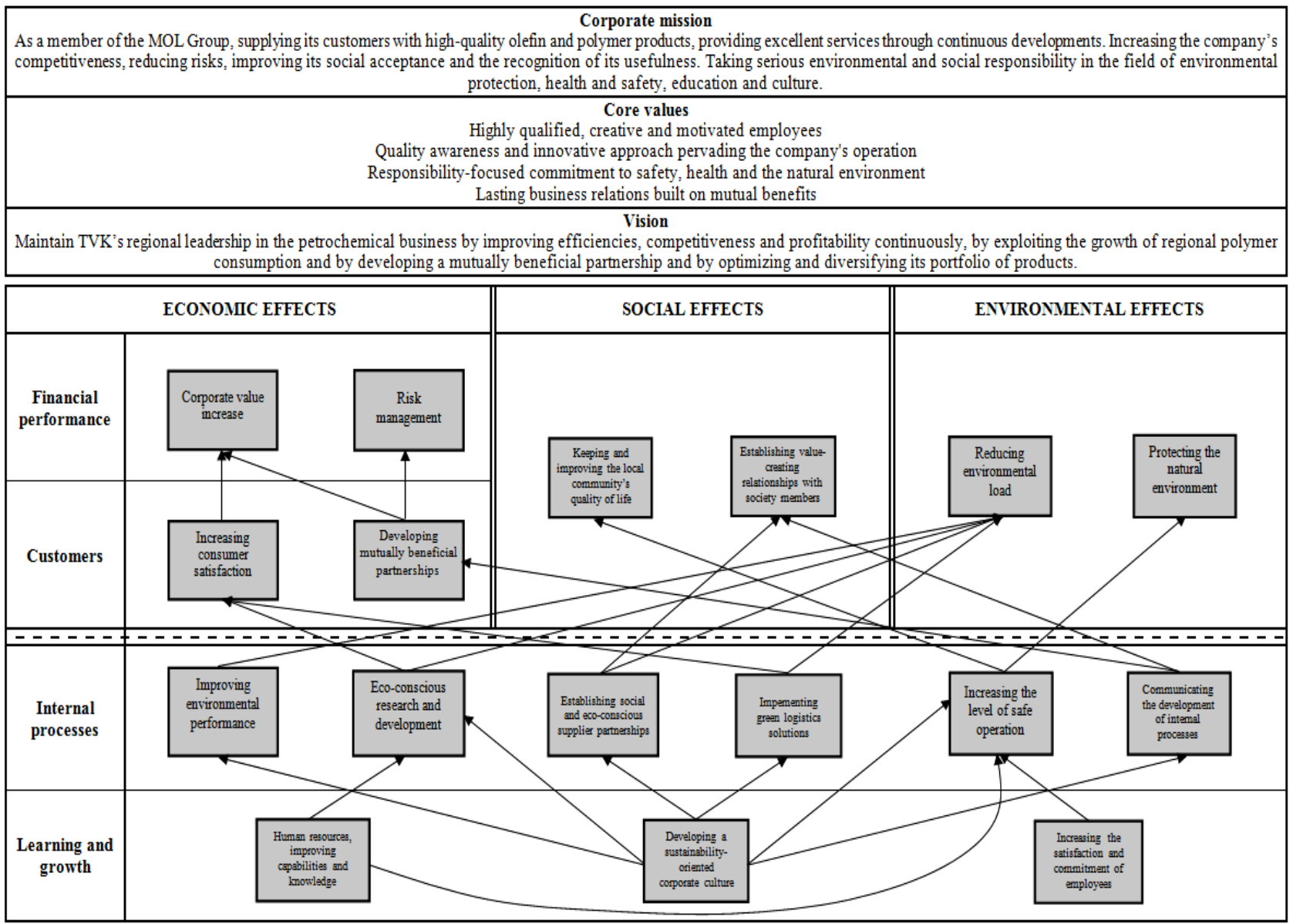

Figure 4. TVK's map of “credible” sustainability strategy (Fulop \& Hernadi, 2012)

The strategy map presented in Figure 4 also highlights the company's internal processes and activities in what pertains to social and environmental issues. One of the most determining elements of internal processes is innovation and, in this case, the company tries to align these innovations with its broader sustainability concerns. For instance, in order to reduce its negative environmental impact, the company has been conducting a research into the production of biologically degradable plastics through the development of new additives. This innovation process has a positive effect on the quality and price of new products, and so allows it to satisfy better customer needs. Indeed, from the customer perspective, one of the key objectives of TVK was defined as being able to increase satisfaction by providing high-quality services and meeting customer demands in an efficient way.

Given the great importance currently attached to the protection of the natural environment, TVK has identified it as one of its main strategic priorities. It has introduced a number of measures to reduce environmental load, including reusing of waste, reducing of fresh water consumption in production processes, and reducing of the emission of pollutants.

\section{SBSC of TVK's “credible” strategy and associated benefits}

The SBSC for TVK's "credible" strategy (see Table 1) was constructed bearing in mind that long-term success and social acceptance not only are reflected in economic indicators. It clarifies the company's strategic goals, the operational goals that stem from them, the indices applied to monitor their fulfilment, as well as the management tools that can facilitate their implementation. This structure allows TVK to monitor its goal pursuit. 
The SBSC of TVK's “credible” strategy (based on the company's annual reports)

\begin{tabular}{|c|c|c|c|c|c|c|c|c|c|}
\hline Perspectives & Strategix gouk & Operative goak & \multicolumn{6}{|c|}{ Strattegic indices } & Efficient management took \\
\hline \multirow{6}{*}{$\begin{array}{l}\text { 1. Fonacial } \\
\text { pefformase }\end{array}$} & \multirow[t]{6}{*}{$\begin{array}{l}\text { 1.1. Corporats vabe increass } \\
\text { 1.2. Ris masagemet }\end{array}$} & \multirow{6}{*}{$\begin{array}{l}\text { 1.1.1. Iorressing ROACE } \\
\text { 1.1.2 Rebuxing eaviroemenal reserves }\end{array}$} & Iodices & 2008 & 2009 & 2010 & 2011 & 2012 & \multirow{6}{*}{ 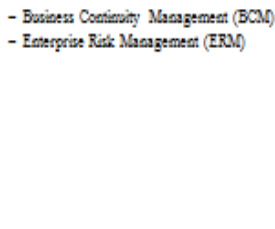 } \\
\hline & & & 1.1. ROE & $\cdot 0,1$ & $-6,69$ & $-0,86$ & $-9,13$ & $-6,55$ & \\
\hline & & & 1.1. EBITDA (mF") & 17703 & 5099 & 13699 & 7429 & 3646 & \\
\hline & & & 1.1. $\mathrm{ROACE}(\%)$ & 2,1 & $-4,5$ & $-0,4$ & $-5,37$ & $-3,49$ & \\
\hline & & & 1.2 Eeviromental seserves (mFi) & 2563 & 1971 & 2030 & 2314 & 2346 & \\
\hline & & & 12 HSE-reland fons & 0 & 0 & 0 & 0,1 & 0 & \\
\hline 2 Comsenters & $\begin{array}{l}\text { 21. Sstiffying convumer demands } \\
\text { 22. Developing muastly beoticial }\end{array}$ & 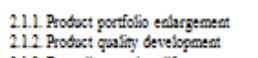 & 21. Customer sairfaction infex (\%) & 14,39 & 19,52 & 15,32 & 16,60 & 19,34 & \multirow{2}{*}{ 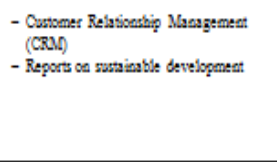 } \\
\hline & partaneraips & 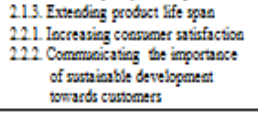 & & & & & & & \\
\hline \multirow[t]{5}{*}{ 3. Ientrosal } & \multirow{5}{*}{ 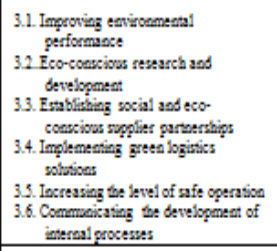 } & \multirow{5}{*}{ 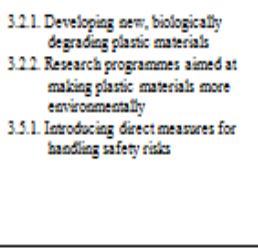 } & 3.1. Enviroemental inversments (mFi) & 65,1 & 252,8 & 85,6 & 315 & 1096,9 & \multirow{5}{*}{ 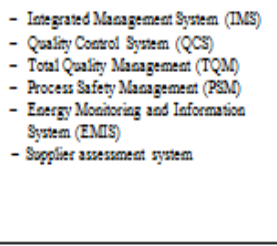 } \\
\hline & & & $\begin{array}{l}3.2 \text { Senvices relaned to resasch and } \\
\text { development (mFi) }\end{array}$ & 28. & 235 & 230 & 198 & 213 & \\
\hline & & & 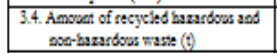 & 308 & 4653 & 743 & 427 & 396 & \\
\hline & & & 3.5. Nember of fire sccistest (pes) & 0 & 0 & 3 & 0 & 2 & \\
\hline & & & & & & & & & \\
\hline \multirow[t]{4}{*}{$\begin{array}{l}\text { 4. Lesming and } \\
\text { gromth }\end{array}$} & \multirow{4}{*}{ 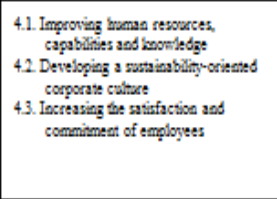 } & \multirow{4}{*}{ 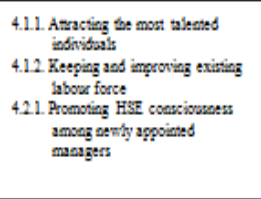 } & $\begin{array}{l}\text { 4.1. Cost of edocation and raining per } \\
\text { capia (F) }\end{array}$ & 150000 & 76212 & 74500 & 67.628 & 66.000 & \multirow{4}{*}{ 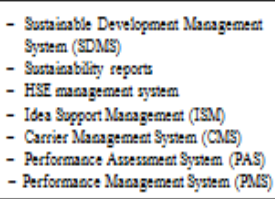 } \\
\hline & & & $\begin{array}{l}\text { 4.1. Nember of raining bouss pers } \\
\text { capia }\end{array}$ & $\begin{array}{l}\text { so data } \\
\text { forad }\end{array}$ & 31,99 & 79,8 & 25,3 & 41,6 & \\
\hline & & & $\begin{array}{l}\text { 43. Nvanber of emplopyes heff from } \\
\text { TVK (persoa) }\end{array}$ & $n 2$ & 44 & 60 & 37 & 112 & \\
\hline & & & 43. Ras of sich have (\%) & 15,8 & 16,4 & 15,3 & 14,2 & 13 & \\
\hline \multirow[t]{6}{*}{ 3. Sociaty } & \multirow{6}{*}{ 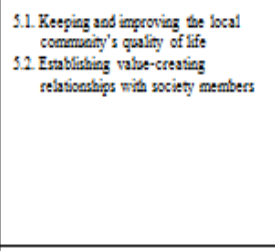 } & \multirow{6}{*}{ 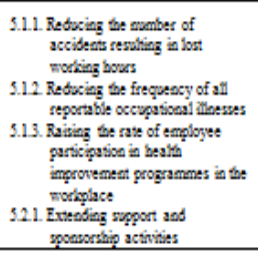 } & & & & & & & \multirow{6}{*}{ 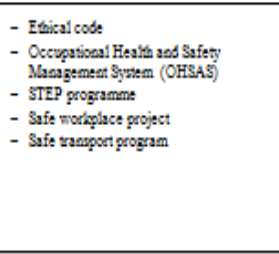 } \\
\hline & & & $\begin{array}{l}\text { 5.1. LTIF (Lont Time Iajoxy } \\
\text { Freçeacy) }\end{array}$ & 0,49 & 0.50 & 0,50 & 0,51 & 1,59 & \\
\hline & & & 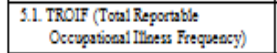 & 0 & 0 & 0 & 0 & 0 & \\
\hline & & & 5.2. Spoasorstip and doansisan (mFi) & 66,7 & 66,9 & 49,89 & 49,99 & 43,75 & \\
\hline & & & $\begin{array}{l}\text { 5.2. Rast of femalt employees } \\
\text { compared wo be wal ruaber of } \\
\text { emologees (\%) }\end{array}$ & 34,5 & 32,5 & 32,6 & 32,1 & 27,4 & \\
\hline & & & & & & & & & \\
\hline \multirow[t]{4}{*}{$\begin{array}{l}\text { 6. Nutzal } \\
\text { exviroumeat }\end{array}$} & \multirow[t]{4}{*}{ 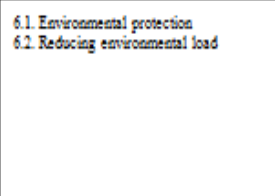 } & \multirow{4}{*}{ 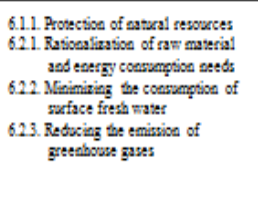 } & 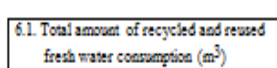 & 934770 & 899944 & 1372993 & 1373.944 & 1.278 .218 & \multirow{4}{*}{ 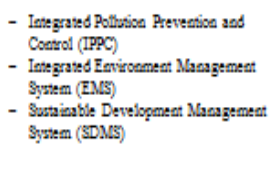 } \\
\hline & & & 62. Natral gas consumptisa (GI) & 23. & 1403194 & 1693172 & 1.167 .828 & 1331224 & \\
\hline & & & 6.2 Ekctricity coasuantisa (GI) & 28. & 1930093 & 2013495 & 1950912 & 1.734 .276 & \\
\hline & & & $6.2 \mathrm{CO}_{2}$ emissisa (i) & 1147068 & 1056552 & 112707 & 1.116721 & 91692 & \\
\hline
\end{tabular}

Source: Company’s Annual Reports (cf. Tiszai Vegyi Kombiaat Nyrt., 2008-2012)

Among the perceived benefits observed, it is worth noting that the SBSC: (1) facilitated a better understanding of the concept of sustainability, as well as of the efforts being made towards it throughout the company; (2) helped to highlight the areas in which sustainability actions were lacking; (3) helped to clarify how social and environmental issues were being integrated into the company's decisionmaking processes and activities; and (4) provided a theoretical guideline for the Sustainable Development Department to plan its operational activities on the basis of long-term sustainability and business excellence objectives.

The expectation is that with time, as familiarity with the SBSC increases and it exerts an ever greater influence on the company culture, the values reported for the strategic indices will exhibit a corresponding improvement. The first glimmerings of this can already be seen in the data presented in Table 1. However, the data presented refer to a period starting in 2008, during which, severely hit by the global financial crisis, the Hungarian economy went into severe recession, with a contraction of $6,8 \%$ in 2009 . Despite the signs of recovery, with $1,7 \%$ growth in
2011, GDP growth was negative again in 2012. As such, the numerical values presented in Table 1 need to be understood within this context.

\section{Conclusion}

Selecting of appropriate sustainability strategy is an increasingly important step in the strategy-planning process; and equally important is then translating of that strategy into action. The present research contributes to closing of the gap between principle and action at the business level, by creating a framework to facilitate the formation and implementation of different sustainability strategies. This is done through the SBSC, which goes beyond mere additions of the environmental and social perspectives, to recognize their interaction with the traditional BSC perspectives, and include sustainability related goals within them. A company's sustainability strategy is thus placed at the center of the SBSC, and its components and the steps required for its development clearly enumerated. 
To illustrate how the formation and implementation of such a SBSC could be carried out in practice, its application in the chemical company was presented. This not only demonstrated the usefulness of the SBSC in pursuing sustainability strategies and business excellence, but constitutes an important addition to the literature, because practical applications of such tools are greatly lacking ( $c f$. Volkery et al., 2006; Niinimaki \& Hassi, 2011; Kardos, 2012). It furthermore highlights the significance of corporate culture in the entire process of developing and implementing of the SBSC, since the introduction of such a system is likely to lead to fundamental changes in the way a company is managed.

These contributions not only add to the theory, but can also be of benefit to policy-makers and/or managers working in the field, and wanting to lead their companies to compliance with the requirements of sustainability. In this respect, it would be of interest to analyze further applications of the tool in different industries and/or companies, particularly those in which sustainability issues were previously not afforded great concern. Longitudinal studies examining the longer term impact of the application of the SBSC would also be of relevance. Finally, from a more theoretical perspective, a research into the critical relationship between culture, structure, leadership and sustainability alluded to above would also be of interest.

\section{Acknowledgements}

An earlier and less complete version of this work was presented at the 2012 International Conference on Management, Knowledge and Learning: Global Empowerment, held in Celje, Slovenia. This research was carried out as part of the TAMOP-4.2.1.B-10/2/KONV2010-0001 project in the framework of the New Hungarian Development Plan, supported by the European Union and co-financed by the European Social Fund. The authors gratefully acknowledge the institutional support of the Tiszai Vegyi Kombinat Public Limited Company.

\section{References}

Agostino, D., \& Arnaboldi, M. (2012). Design Issues in Balanced Scorecards: The "What" and "How" of Control. European Management Journal, 30(4), 327-339. http://dx.doi.org/10.1016/j.emj.2012.02.001

Atkinson, H. (2006). Strategy Implementation: A Role for the Balanced Scorecard? Management Decision, 44(10), 14411460. http://dx.doi.org/10.1108/00251740610715740

Bieker, T. (2003). Sustainability management with the balanced scorecard. In S., Karner, I. Oehmeand, \& U. Seebacher (Eds.), Proceedings of 5th international summer academy on technology studies (pp. 17-34), Deutschlandsberg, Austria.

Bieker, T., \& Waxenberger, B. (2002). Sustainability balanced scorecard and business ethics: Developing a balanced scorecard for integrity management, Proceedings of the 10th conference of the greening of industry network, Goteborg, Sweden.

Bieker, T., Dyllick, T, Gminder, C., \& Hockerts, K. (2002). Towards sustainability balanced scorecard: Linking environmental and social sustainability to business strategy, St. Gallen-Fontainebleau: IWÖ-HSG and INSEAD.

Butler, J., Henderson, S., \& Raiborn, C. (2011). Sustainability and the Balanced Scorecard: Integrating Green Measures into Business Reporting. Management Accounting Quarterly, 12(2), 1-10.

Chang, W., Tung, Y., Huang, C., \& Yang, M. (2008). Performance Improvement after Implementing the Balanced Scorecard: A Large Hospital's Experience in Taiwan. Total Quality Management \& Business Excellence, 19(11), 1143-1154. http://dx.doi.org/10.1080/14783360802323560

Dias-Sardinha, I., Reijnders, L., \& Antunes, P. (2002). From Enviornmental Performance Evaluation to Eco-Efficiency and Sustainability Balanced Scorecards. Environmental Quality Management, 12(2), 51-64. http://dx.doi.org/ 10.1002/tqem.10063

Dias-Sardinha, I., Reijnders, L., \& Antunes, P. (2007). Developing Sustainability Balanced Scorecards for Environmental Services: A Study of Three Large Portuguese Companies. Environmental Quality Management, 16(4), 13-34. http://dx.doi.org/10.1002/tqem.20139

Dyllick, T. (1999). Environment and competitiveness of companies. In D., Hitchens, J. Clausenand, \& K. Fichter (Eds.), International environmental management benchmarks. Berlin: Springer.

Epstein, M., \& Wisner, P. (2001). Good Neighbours: Implementing Social and Environmental Strategies with the BSC. Balanced Scorecard Report, Harvard Business School Publishing, 3-6.

Fernandes, K., Rajab, V., \& Whalley, A. (2006). Lessons From Implementing the Balanced Scorecard in a Small and Medium Size Manufacturing Organization. Technovation, 26(5/6), 623-634. http://dx.doi.org/10.1016/j. technovation.2005.03.006

Ferreira, F. (2013). Measuring Trade-offs among Criteria in a Balanced Scorecard Framework: Possible Contributions from the Multiple Criteria Decision Analysis Research Field. Journal of Business Economics and Management, 14(3), 433-447. http://dx.doi.org/10.3846/16111699.2011.631744 
Gyula Fulop, Bettina Hernadi, Marjan Jalali, Ieva Meidute-Kavaliauskiene, Fernando Ferreira. Developing of

Figge, F., Hahn, T., Schaltegger, S., \& Wagner, M. (2002). The Sustainability Balanced Scorecard: Linking Sustainability Management to Business Strategy. Business Strategy and the Environment, 11(5), $269-284$. http://dx.doi.org/10.1002/bse.339

Fink, A., Marr, B., Siebe, A., \& Kuhle, J. (2005). The Future Scorecard: Combining External and Internal Scenarios to Create Strategic Foresight. Management Decision, 43(3), 360-381. http://dx.doi.org/10.1108/00251740510589751

Fülöp, G., \& Hernadi, B. (2012). Corporate sustainability - Strategic alternatives and methodology - Implementation. In V. Dermol, N. Sirca, G. Dakovic \& U. Lindav (Eds.), Proceedings of the 2012 international conference on management, knowledge and learning: Global empowerment (pp. 109-120), Celje, Slovania.

Fulop, G., \& Pelczne, I. (2011). Fenntarthatosagi vallalati strategiak megvalositasa balanced scorecard alkalmazasaval. Proceedings of the 8th biannual scientific conference on knowledge-based society, knowledge-creation, knowledge-transfer and changing scale of values, Miskolc-Lillafüred, Hungary.

Garvare, R., \& Johansson, P. (2010). Management for Sustainability: A Stakeholder Theory. Total Quality Management \& Business Excellence, 21(7), 737-744. http://dx.doi.org/10.1080/14783363.2010.483095

Ghazinoory, S., \& Soofi, A. (2012). Modifying BSC for National Nanotechnology Development: An Implication for "Social Capital" Role in NIS Theory. Technological and Economic Development of Economy, 18(3), 487-503. http://dx.doi.org/10.3846/20294913.2012.707630

Ghobadian, A., Viney, H., Liu, J., \& James, P. (1998). Extending Linear Approaches to Mapping Corporate Environmental Behaviour. Business Strategy and the Environment, 7(1), 13-23. http://dx.doi.org/10.1002/ (SICI)1099-0836(199802)7:1<13::AID-BSE133>3.0.CO;2-D

Jones, P. (2011). Designing an Effective Environmental Balanced Scorecard. Available from internet: http://www.excitant.co.uk/wp-content/uploads/2012/07/Excitant_WP_Designing_Environmental_Balanced _Scorecard.pdf [November, 2013].

Kaplan, R., \& Norton, D. (1992). The Balanced Scorecard: Measures that Drive Performance. Harvard Business Review, 70(1), 71-79.

Kaplan, R., \& Norton, D. (1996). Using the Balanced Scorecard as a Strategic Management System. Harvard Business Review, 74(1), 75-85.

Kaplan, R., \& Norton, D. (2001). The strategy-focused organization. Boston, MA: Harvard Business School Press.

Kaplan, R., \& Norton, D. (2004). Strategy map: Converting intangible assets into tangible outcomes. Boston, MA: Harvard Business School Press.

Kardos, M. (2012). The Reflection of Good Governance in Sustainable Development Strategies. Procedia - Social and Behavioral Sciences, 58(1), 1166-1173. http://dx.doi.org/10.1016/j.sbspro.2012.09.1098

Kolk, A. (2000). The economics of environmental management. London: Prentice Hall.

Kraus, K., \& Lind, J. (2012). The Impact of the Corporate Balanced Scorecard on Corporate Control: A Research Note. Management Accounting Research, 21(4), 265-277. http://dx.doi.org/10.1016/j.mar.2010.08.001

Liming, H., Haque, E., \& Barg, S. (2008). Public Policy Discourse, Planning and Measures Toward Sustainable Energy Strategies in Canada. Renewable and Sustainable Energy Reviews, 12(1), 91-115. http://dx.doi.org/ 10.1016/j.rser.2006.05.015

Niinimaki, K., \& Hassi, L. (2011). Emerging Design Strategies in Sustainable Production and Consumption of Textiles and Clothing. Journal of Cleaner Production, 19(16), 1876-1883. http://dx.doi.org/10.1016/j.jclepro.2011.04.020

Othman, R. (2006). Balanced Scorecard and Causal Model Development: Preliminary Findings. Management Decision, 44(5), 690-702. http://dx.doi.org/10.1108/00251740610668923

Petrokaite, K., \& Stravinskiene, J. (2013). Corporate Reputation Management Decisions: Customer's Perspective. Inzinerine Ekonomika-Engineering Economics, 24(5), 496-506. http://dx.doi.org/10.5755/j01.ee.24.5.3920

Sarmento, M., Durao, D., \& Duarte, M. (2007). Evaluation of Company Effectiveness in Implementing Environmental Strategies for a Sustainable Development. Energy, 32(6), 920-926. http://dx.doi.org/10.1016/j.energy.2006.09.011

Simon, A., Bernardo, M., Karapetrovic, S. \& Casadesus, M. (2013). Implementing Integrated Management Systems in Chemical Firms. Total Quality Management \& Business Excellence, 24(3/4), 294-309. http://dx.doi.org/ $10.1080 / 14783363.2012 .669560$

Sminia, H. (2005). Strategy Formation as Layered Discussion. Scandinavian Journal of Managemnet, 21(3), $267-291$. http://dx.doi.org/10.1016/j.scaman.2004.09.002

Tiszai Vegyi Kombinat Nyrt. (2008-2012). Fenntarthatosagi jelentes, Eves jelentes, Eves beszamolo, Uzleti jelentes [Company's Annual Reports].

Ubius, U., \& Alas, R. (2012). The Impact of Corporate Social Responsibility on the Innovation Climate. Inzinerine Ekonomika-Engineering Economics, 23(3), 310-318. http://dx.doi.org/10.5755/j01.ee.23.3.1935 
Volkery, A., Swanson, D., Jacob, K., Bregha, F. \& Pinter, L. (2006). Coordination, Challenges, and Innovations in 19 National Sustainable Development Strategies. World Development, 34(12), 2047-2063. http://dx.doi.org/10.1016/j. worlddev.2006.03.003

Wong, F., Lam, P., \& Chan, E. (2009). Optimising Design Objectives using the Balanced Scorecard Approach. Design Studies, 30(4), 369-392. http://dx.doi.org/10.1016/j.destud.2008.10.004

Wynder, M. (2010). Chemico: Evaluating Performance based on the Balanced Scorecard. Journal of Accounting Education, 28(16), 221-236. http://dx.doi.org/10.1016/j.jaccedu.2011.03.006

Gyula Fülöp, Bettina Hernadi, Marjan Jalali, Ieva Meidutė-Kavaliauskienė, Fernando Ferreira

Tvarumo subalansuotụ rodiklių metodikos tobulinimas chemijos pramonèje: preliminarūs atvejo analizès rezultatai

Santrauka

Moksline problema. Globalizacija, etinė kompetencija, kokybè, informaciniu ir komunikaciniu technologiju (IKT) taikymas, darbo jẻgos ịvairovè ir verslo kompetencijos kelia vis didesnị susirūpinimą 21-ojo amžiaus kompanijoms. Visa tai susijungia, nes išorinès aplinkos dinamiškumas ir sudètingumas didèja, todèl strategijos kūrimas tampa ypač svarbus kompanijai išlikti, taip pat jos sèkmei ir gebèjimui pasiekti patvarų konkurencini pranašumą. Patvarumo klausimai taip pat svarbūs įmonėms, kurios nori pasiekimų šiame naujame kontekste. Taigi, patvarumas, viena iš svarbesniu sąlygų kuriant strategiją. Imonės patvarumo reikalauja tiek vidaus, tiek išorès suinteresuotosios šalys, taip pat visuomenė bei vartotojai. Tai reiškia, kad kompanija turi turèti strategiją, kuri atitiktų ir dabartinių, ir būsimų kompanijos suinteresuotujų šalių lūkesčius, nedarydama jokių kompromisų gebëjimų ir gabumų požiūriu. Taigi įmonè turi ịgyvendinti savo strateginius tikslus ir priemones, kad išliktų globaliame pasaulyje. Viena iš tokių priemonių, kuri dabartiniu metu vis dažniau taikoma yra subalansuota apskaita (SA). Mintis panaudoti SA aplinkos valdymo tikslams, nèra nauja, o bendras SA metodas buvo sudarytas, norint kartu prijungti socialines ir aplinkosaugos perspektyvas. Tačiau, prijungus šiuos du būdus prie SA, nepavyksta išnagrinèti ju specifiniu komponentų, taip pat jų įtakos tradicinèms perspektyvoms. Toks metodas, be abejo gali pakenkti socialiniam ir aplinkos apsaugos tvarumui. Pirma, socialinių ir aplinkos apsaugos veiksnių suskirstymas ị individualias perspektyvas, o ne ieškojimas bendrų kriterijų visai veiklai ir priimamiems sprendimams, gali būti labiau skaldantis, nei integruojantis. Antra, tokie paprasti pridejimo metodai sutelkia dèmesị daugiau ị kompanijos veiksmų socialines ir aplinkos apsaugos pasekmes.

Tyrimo tikslai ir naujumas: Šis darbas yra parengtas, remiantis ankstesniais Bieker (2003) bei Fülöp ir Hernadi (2012) darbais, kurie svarbūs analizuojant ir aptariant įmonių strategijos patvarumo ir verslo kompetencijos sėkmingo bendravimo ir įgyvendinimo bei praktinio pritaikymo klausimus.

Šiame darbe siekiama sukurti sistemą, kuri padètų įmonèms nustatyti tai, kas svarbu analizuojant tvarumą ir kuriant tvarumo strategijas.

Taigi šio tyrimo tikslas: užpildyti spragą tiek teorinių, tiek praktinių žinių, kuri yra atsiradusi tarp teorijos ir praktikos (verslo lygiu), prieš tai sukuriant Patvarumo subalansuota apskaita (PSA), kuri gali turèti ịtaką skirtingų patvarumo strategijų formavimui ir įdiegimui. Reikia paminèti tai, kad šiame straipsnyje aprašomas praktinis šios PSA struktūros pritaikymas didžiausiose Vengrijos chemijos pramonės kompanijose. Bus praktiškai parodytas ištobulintos struktūros veikimas ir panaudojimas.

Projektavimo ir tyrimo metodai: Išanalizavus teorinę literatūrą, buvo nustatyta PSA struktūra ir jos plètrai bei praktiniam taikymui reikalingi etapai. Be to, kas paminèta anksčiau, šios struktūros sukūrimo tikslas buvo pateikti kompanijoms praktišką instrumentą, kurị naudojant, būtų ịtrauktas patvarumas kuriant ir diegiant savo strategijas. Tikslas buvo pabandyti ịvertinti struktūros taikymą praktikoje, ne tik norint padidinti sukurto instrumento pagrịstumą, bet taip pat ir dèlto, kad mūsų interesai susiję su struktūros kūrimu, kuris gali padèti kompanijoms nustatyti visus svarbius patvarumo tikslus ir sukurti patvarumo strategiją. Kompanija pasirinkta dèl jos dydžio ir reikšmès šalies mastu, taip pat dèl spręstinų socialinių ir aplinkosaugos klausimų, jos išmanymas tradicinès SA, ir galiausiai jos prieinamumas ir noras bendradarbiauti su tyrimo projektu. Iš tiesų, TVK yra viena iš svarbiausių Vengrijos koorporacijų ir jau daugiau nei šešerius metus naudojo tradicinę SA (prieš tai, kai pirmą kartą susitiko su tyrèjais dèl PSA tobulinimo). Vyko susitikimai su aukščiausia vadovybe, Patvarumo vystymo skyriumi, kuris yra atsakingas už kompanijos sveikatos ir saugumo, draudimo ir aplinkos apsaugos klausimus. Nors tai pavienis ịdiegimo atvejis, galimybe ịdiegti PSA šioje kompanijoje pateikè daug ịdomių ir naudingų duomenų apie struktūros aktualumą ir tinkamumą kompanijoms, norinčioms pirmauti, ịtraukiant i jų strategiją patvarumą.

Rezultatai ir praktinè reikšmė: Šiame darbe pasiūlyta PSA yra sudaryta pagal tradicinę SA, pateikiant platesnę struktūrą, kur suinteresuotuju pusių ir patvarumo dydžiai yra integruoti su tradicinèmis perspektyvomis. To rezultatas yra Patvarumo SA, apimanti kitokị turinị ir kitokią struktūrą. Ji pristato socialines ir aplinkos apsaugos perspektyvas, todèl su šiomis perspektyvomis susiję tikslai gali būti nubrèžti aiškiai ir tiesiogiai. Ši struktūra "peržengia“" paprastą papildymą, nes su patvarumu susiję tikslai yra nagrinèjami kiekvienoje tradicinèje perspektyvoje ir yra atsižvelgiama ị sąveiką tarp jų ir dviejų naujų dydžių. Papildant struktūros vystymą ir pateikiant kiekvieno etapo įdiegimo vadovą, šiuo darbu buvo ieškota būdo kaip ịdiegti šią PSA kompanijos kontekste. Tarp suvokiamos naudos, pastebėtos taikant šią struktūrą vienoje iš didžiausių Vengrijos kompanijų, verta paminèti, kad SA: (1) leido geriau suprasti patvarumo koncepciją ir kompanijos pastangas jai pasiekti; (2) padejo pabrěžti sritis, kuriose trūko patvarumo veiksmų; (3) padẻjo paaiškinti kaip socialiniai ir aplinkos apsaugos klausimai buvo integruoti $\mathfrak{i}$ kompanijos sprendimų prièmimo procesus ir veiklą; ir (4) pateikè teorines gaires Patvaraus vystymo skyriui, kad šis suplanuotu savo operatyvinę veiklą, remdamasis ilgalaikio patvarumo ir verslo kompetencijos tikslais. Nors tai pavienis pritaikymas, šie rezultatai yra daug žadantys, atsižvelgiant ị PSA potencialą, kaip ịrankị, skirtą integruoti kitas ir būsimas suinteresuotas šalis (įskaitant aplinką) ir jų interesus ị kompanijos veiklą ir taip potencialiai igyjant konkurencinị pranašumą.

Raktažodžiai: subalansuota apskaita, verslo veikla, bendra strategija, ekonominè plètra, patvarumo strategija.

The article has been reviewed.

Received in February, 2014; accepted in June, 2014. 